centre of the city, it is but a short distance from several of the more important provincial forests where field work is performed daily by the students.

The first class started on July 29, 1946, and numbered twenty-five students, all except one of whom were ex-service men. By Christmas this number had been reduced to twenty and it is expected that approximately this number will graduate the latter part of June, 1947.

These men are being trained for positions as forest rangers or for positions in private industry. Typewriting and Bookkeeping are included in the heavy curriculum of sixteen major subjects.

The students have responded amazingly well to instruction and it is the unanimous opinion of forest officers that the results obtained at this school to date are far superior to those obtained, in anything like the corresponding amount of time, under training on the job.

The Saskatchewan Department of Natural Resources and Industrial Development has taken the advice of men like Robson Black seriously and is now hard at work preparing men for those duties and responsibilities lying between those of the forester and the untrained forest worker. It is on these men that much of the success of Saskatchewan's rapidly expanding forest program will depend.

F. H. Hewett.

\title{
FORESTRY MEMORIAL SCHOLARSHIP
}

The President of the University of Toronto, Dr. Sidney Smith, announced recently that the Forestry Memorial Scholarship of $\$ 250.00$ for the session 1946-47 had been divided equally between D. L. Hagar, D.F.C., and P. A. Mick, A.F.C., first year students in the Faculty of Forestry. The scholarship was awarded on the basis of their standing in the Ontario Grade XIII examinations.

Both men are former members of the R.C.A.F. Mr. Hagar, who is the son of Mr. and Mrs. D. L. Hagar of Port Arthur, attended high school there and on his return from service overseas as a Flying Officer took his Grade XIII examinations at the Ontario Training and Re-establishment Institute in Fort William.

Mr. Mick is the son of Mrs. Georgina Mick of Powassan, Ontario. He attended high school in North Bay and took the Grade XIII Ontario Train. ing and Re-establishment Institute course there on his return from service overseas as Flight-Lieutenant.

This is the fifth award of the Forestry Memorial Scholarship. It was established by alumni and friends of the Faculty in honour of former members of the Faculty of Forestry staff and in memory of graduates and under. graduates who have lost their lives in war activities or in civilian pursuits.

Announced by W. J. Dunlop,

University of Toronto, November 12, 1946. 